\title{
Parents' Perceptions of Secondary Physical Education
}

\author{
Lauren Earley ${ }^{1}$, Matthew Fleet ${ }^{2}$ \\ ${ }^{1}$ University of Worchester \\ ${ }^{2}$ Solent University, UK \\ Correspondence: Matthew Fleet, Solent University, UK.
}

Received: March 2, 2021

doi:10.11114/ijce.v4i2.5350
Accepted: September 8, $2021 \quad$ Online Published: September 13, 2021

URL: https://doi.org/10.11114/ijce.v4i2.5350

\begin{abstract}
There is a large quantity of research (Alguacil, 2018; Ciotto \& Gagnon, 2018; McKenzie and Lounsbery, 2014) which states the importance Physical Education (PE) has in pupils' lives. However, there is a state of decline for the status of the subject (Harris, 2018; Kirk et al., 2013). Parents perception is an under-researched area (Na, 2015; Yilmaz, 2018), especially in the UK, therefore, it is important parents' beliefs are explored to understand an important stakeholder's viewpoint. Purpose: To explore and gain an understanding of the perception's parents have of Secondary PE, investigating what the perceptions are and why they have them. Methodology: This study uses a mixed-methods exploratory design to discover, the perceptions parents have on Secondary school PE, using a quantitative online survey and qualitative semi-structured interviews. 263 parents/guardians completed the survey, which was then followed by 8 parents taking part in the interviews. Results: From the data sets collected 5 themes were identified: Importance of PE; Teacher-Pupil relationship; PE in relation to other subjects; competitive nature of PE and impact PE has on confidence. $50 \%$ percent of parents did believe that PE is as important as subjects such Maths, English and Science, but, in comparison to other subjects $61 \%$ of parents do not favour PE overall. With results demonstrating the growing awareness parents have of the crucial role PE plays in health and wellbeing for pupils. Conclusion: Although parents understand the importance of PE, parents perceptions differ on some aspects of the subject. This study is a starting point for other researchers and should be continued to be researched to support PE in the curriculum.
\end{abstract}

Keywords: parents, perceptions, secondary, physical, education

\section{Introduction}

Children are shaped through their experiences at home and school. Therefore, parents and teachers, acting as key role models in a young person's life, are extremely important when it comes to these experiences (Raudsepp, 2006). Various academics (Bartram, 2006; Davis-Kean, 2005; Desimone, 1999; Erdener and Knoeppel, 2018; Erola et al., 2016; Feinstein and Sabates, 2006) have undertaken research on the influence a parent can have on a child's education. However, there are limited studies into parental influence and their perception of Physical Education (PE) (Na, 2015; Yilmaz, 2018). Research has indicated that if a child is supported and persuaded by their parents to be active physically, they are more likely to continue to be so later in life (Beets et al., 2010; Thompson et al., 2010; Wright et al., 1997). Individual engagement (or) interest in Physical Activity (PA), PE or sport is also understood to be heavily influenced by school experiences, (Capel \& Whitehead, 2015; Green, 2008; Kirk et al., 2013; Randall \& Fleet, 2020), and shaped by parental influence (Beets et al., 2010; Davison, 2004; Thompson et al., 2010) therefore positive influences can encourage lifelong participation. In the UK PE is a compulsory element of the national curriculum (Capel \& Whitehead, 2015). Yet in spite of this formal status, since the early 1970s, PE 'has been in a state of decline and marginalization' (Kirk, p45, Cited in Green 2008). Numerous academics have noted the need to improve the subject's status (Bailey, 2010; Blair \& Capel, 2011; Capel \& Whitehead, 2015; Green, 2008; Green and Hardman, 2011; Harris, 2018; Kirk et al., 2013; Randall et al., 2016; Stidder and Hayes, 2010).

There are many conflicting views on the value and purpose of PE; sampling a variety of activities, to get fit, improve mental health, or to be physically active have been proposed (Andrew et al., 2017; Bailey et al., 2009; Green, 2003; Green and Hardman, 2005; Hastie, 2016; Stolz, 2014). There is some consensus over the purpose of education which is the acquisition of valuable knowledge and according to White (2006), this is made up of two clear distinct forms Propositional (or sometimes called theoretical) which comprises of information and judgement; and Practical which consists of skills or abilities. Practical knowledge is the most significant form of knowledge in relation to the subject of PE. However, it is 
theoretical knowledge relating to Science, Technology English and Maths (STEM) subjects which are frequently viewed as more valuable and have the capability to change viewpoints, generate balanced logical thinking and independence (Brown et al., 2011; Griggs, 2007, 2010; Oxley, 1998). Consequently, this assumption underpins an academic curriculum focusing on intellectual taxonomies, centering on approximately seven or eight academic subjects. As PE is not focused on the attainment and mastery of theoretical knowledge, some argue that it is non-academic and thus non-educational (McNamee, 2005; Reid, 1996). This in part instigated recent changes to make the subject more academic the recent changes were in part an attempt to prevent its status being marginalised and improve the educational worth, whilst being in a heavily contested period for curriculum space (Fleet, 2020; Reid, 1996). In recent years those working in PE have endeavoured to justify the educational value of PE by acknowledging the contribution it makes to character development, moral education, health education and aesthetic education (Corredor, 2015; Evans, 1986). Contemporary PE curriculums (DfE, 1989, 2013, 2014), have veered towards a dynamic hybrid, recognising the cultural value in sport and the educational nature and worth of the activities that make up PE.

\section{Importance of PE}

Statistics have shown that $20 \%$ of girls and $23 \%$ of boys aged $5-15$ years are performing the advised amount of PA per day in England (Health Survey for England, 2018). The recommended time for 5-18-year-olds is 60 minutes a day (NHS, 2018; Trigwell et al., 2015). Alguacil (2018) highlighted the importance PE has on influencing lifelong participation in PA. Currie et al, (2011) found there to be an increased risk in pupils developing unhealthy behaviours such as physical inactivity, because of sedentary habits developed at a young age. Therefore, it is vital that pupils have opportunities and positive experiences of PA in school so they are able to continue these into adult life.

Pupils are able to develop and transfer skills they learn throughout experiences of quality PE after their statutory school education (McKenzie and Lounsbery, 2014; Trost et al., 1997). There is evidence to suggest PE supports the development of collaborative and interpersonal skills, such as communication, responsibility, and decision-making (Houston and Kulinna, 2014). Furthermore, Na (2015) reported PE develops social behaviours such as etiquette, ethical behaviour, positive interaction, teamwork and cooperation. It could be argued this is why PE is a unique subject (Ciotto \& Gagnon, 2018), as it supports and develops vital 'life' skills. Additionally many academics (Bailey et al., 2009; Inchley et al., 2011; Morgan et al., 2012; Perlman, 2014; Welk and Eklund, 2005) suggest that the subject improves pupils' self-esteem and regular PA has been recognised to decrease stress, anxiety and depression (Hassmén et al., 2000). Hence, PE lessons which are well planned and delivered will be able to support and contribute to the improvement of pupils' psychological health (Bailey, 2006). In addition, pupils who perform well academically, achieving high grades, have been found to be physically active and many practitioners have found a positive correlation between academic achievement and physical fitness (Anderson \& Minke, 2007; Chomitz et al., 2009; Erwin et al., 2012; Green et al., 2007; Haapala, 2013; Miller et al., 2005; Shephard, 1996; Singh et al., 2012; Wittberg et al., 2010).

However, it is important to recognise that there is evidence to suggest that PE in its current form is not liked by all and has a limited impact on encouraging PA in later life, therefore positive change is clearly necessary (Strean, 2009; Cardinal et al., 2013). It is evident that there is dissidence over the true value and purpose of the subject (Green and Hardman., 2005; Green 2003; Stotlz, 2014; Hastie, 2016; Bailey., et al 2009; Lopes., et al, 2017) with the subject needing to become more inclusive and genuinely provide the opportunity to form lasting, positive memories and to encourage lifelong participation (OECD, 2019; Cardinal et al., 2013).

The National Curriculum for PE (NCPE) has encountered condemnation for being elitist, white, upper-middle class and male dominated (Kirk and Tinning., 1990). This suggests that the curricular was not appropriate for all where the political ideology of elite success was pursued rather than the interests of all (Whitehead, 2010). Creating an interesting paradoxical situation where the NCPE proposes a comprehensive and balanced curriculum for all and increasing mass participation and PA, while also endeavouring to accomplish the government's objectives of being a platform for elite sport (Piotrowski, 2000; Capel \& Whitehead., 2015; Kirk and Gorely., 2000; Bailey., et al., 2009; Houlihan and Green., 2006). This ambiguity of aims is not faced within any other secondary subject. The customary teaching approach for PE focussing on talent development is inharmonious with promoting inclusion and equity for all (Penney, 2002).

\section{Parental Influences}

An individual's engagement in PA, PE or sport is believed to be heavily influenced by their school experiences, (Capel \& Whitehead, 2015; Green, 2008; Kirk et al., 2013). Therefore, their experiences develop their PA and dependent on the experiences lead to the amount of PA they do as an adult (Mulvihill et al., 2000; Ornelas et al., 2007; Telama et al., 1997; Thompson et al., 2010). However, many academics (Brustad, 1996; Clement, Brooks, and Wilmoth, 2009; Li et al., 2007), have found children's perceptions are impacted by their parents' beliefs regarding PA. Furthermore, academics (Campbell et al., 2007; Dwyer et al., 2008; Woods et al., 2012) have also stated parents are more likely to transport, facilitate and encourage their children to have active routines. However, Trigwell et al. (2015), found parents lacked awareness of the 
PA recommendations and assumed school would be their child's main provider for PA. This suggests not all parents are completely aware of what PE entails and proposes parents need to be educated on PE.

Jin et al. (2011) found that when pupils make their Key Stage 4 option choices over $80 \%$ sought advice from parents and over $90 \%$ of those who did found it useful. However, it should be noted that parental involvement in the pupil's academic self-efficacy is under-researched (Fan and Williams, 2010). In relation to PE, Olivares et al. (2015) state that parent influence on PE is greater than the influence of the PE teacher. To encourage positive parental involvement first their perceptions and beliefs need to be understood about school subjects and educational topics (Na, 2015; Sheehy, 2006). Studies on parental perception have been conducted globally in countries such as Ireland (Coulter et al., 2019), USA (Na, 2015; Sheehy, 2006) and Turkey (Yilmaz, 2018). With limited studies in UK relating to PE, focusing on pupil perception there is rationale to further understand parent perception (Alguacil, 2018; Bebetsos \& Antoniou, 2008; Carlson, 1995; Hodge and Jansma, 1999; Koca et al., 2005; Subramaniam and Silverman, 2007; Ünlü, 2012).

\section{Methods}

\section{Design}

A mixed-methods explanatory approach was used to fulfil the aims of this study and take into account the strengths and minimise the weaknesses of both quantitative and qualitative methods (Cohen et al., 2018; Johnson and Onwuegbuzie, 2004; Teddlie and Tashakkori, 2009). Qualitative data facilitated further explanation and built upon the initial quantitative results (Creswell and Plano Clark, 2018). The research started with the use of an online survey (quantitative). The survey informed the choice of questions for the semi-structured interviews (qualitative) and helped explain the initial quantitative data.

\section{Participants}

Participants were selected through purposeful sampling and were parents who have a child in Secondary Education (1116 years old) in the UK (Cohen et al., 2018). A total of 263 parents/guardians responded to the online survey: 21 Fathers, 234 Mothers and 8 others (guardians). Of parents/guardians who completed the survey, 8 were interviewed after showing interest in wanting to continue to participate in the research. Social media was used to find participants with a predetermined selection criteria of having a child in secondary education. It is recognised that there is a disproportion of males to females. Van Holland De Graaf (2018) states mothers still spend considerably more time with their children than fathers.

\section{Data collection}

\section{Survey}

An adapted version of Öncü and Güven's (2011) 'Parents attitude scale towards physical education class' was utilised incorporating features of the work from Yilmaz (2018). This survey has 21 statements using a 4-point Likert scaled answer format, this produced an ipsative measure where no indifferent option is available (Cohen et al., 2018). The aim was to explore 4 factors; perceptual, functional, importance, and support Öncü and Güven (2011). Some of the statements were negative, however, the majority of the statements were positive (Yilmaz, 2018). The survey data was collected first with the use of SurveyMonkey®. Statements were randomised, utilising the features of the available computer software.

\section{Interviews}

Semi-structured interviews allowed the gathering of rich data which help to build a holistic picture of why parents had their perception of PE. The face-to-face interviews, lasting approximately 40 minutes, at mutually aggregable location, they focused on the key findings from the quantitative data collected with the online survey. Semi-structured interviews (Flick, 2014; Jones et al., 2013; Silverman, 2016) were used as they allow a researcher to explore and develop an understanding of the perceptions the participants have when talking about what they know and how they feel. This approach allowed flexibility to probe the parental perception where required (Silverman, 2016).

\section{Data Availability Statement}

Data available on request from the authors.

\section{Data analysis}

The online quantitative survey was analysed using descriptive statistics and to express the data, means and standard deviation were used. Furthermore, the qualitative semi-structured interviews were transcribed verbatim from the voice recorded file, to maintain confidentiality all identifying information was removed. Transcripts were then coded using thematic analysis (Cohen et al, 2018; Roulston, 2001).

\section{Ethical Considerations and Acknowledgements}

Prior to data collection, ethical approval was obtained. Confidentiality and anonymity were maintained throughout the 
research process, ensuring the identification of participants was disguised. Furthermore, small parts of the transcripts were removed to protect anonymity and retain validity. Participants were informed of their right to withdraw from the process at any time (Bryman, 2008) and were asked to confirm if the transcripts were accurate of the interviews.

\section{Results}

There were 4 factors explored in the quantitative online survey perceptual; functional; importance; and support with the option of Strongly Agree (1) to Strongly Disagree (4).

Table 1. Scoring Distributions of online survey

\begin{tabular}{ccccc}
\hline Factor & Items & Mean & SD & Outcome \\
\hline Perceptual & 8 & 3.62 & 0.14 & Disagree \\
Functional & 5 & 2.39 & 0.09 & Inconclusive \\
Support & 4 & 1.87 & 0.2 & Agree \\
Importance & 4 & 2 & 0.34 & Agree \\
\hline
\end{tabular}

Table 1 shows the collective results of the survey. These findings suggest parents' perceptions are positive as they tend to disagree with the negative statements relating to PE. In addition, the results of the survey suggest parents agree that PE is an important subject. However, when comparing PE to other subjects' $61 \%$ of parents do not favour PE. Therefore, this was an area that was further explored through interview.

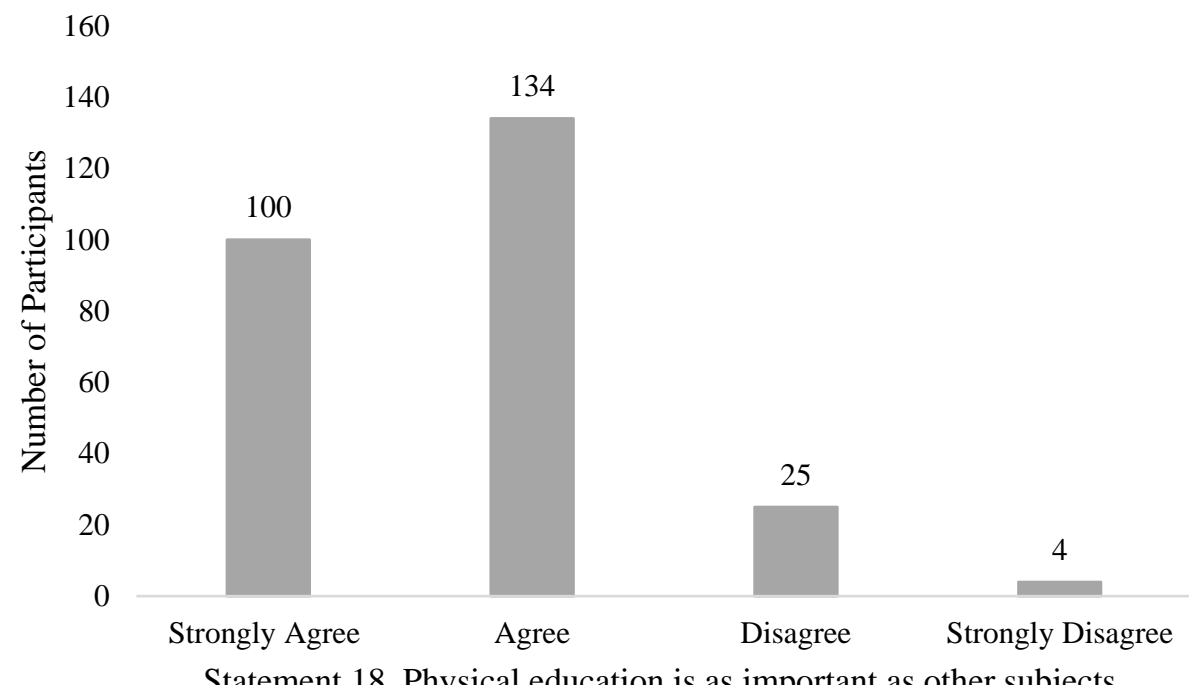

Figure 1. Survey results of statement 18

Figure 1. suggests the vast major of parents think PE is an important subject and has a place in the curriculum. However, the survey also explored the perceptions parents have of PE in regard to other curriculum subjects. 


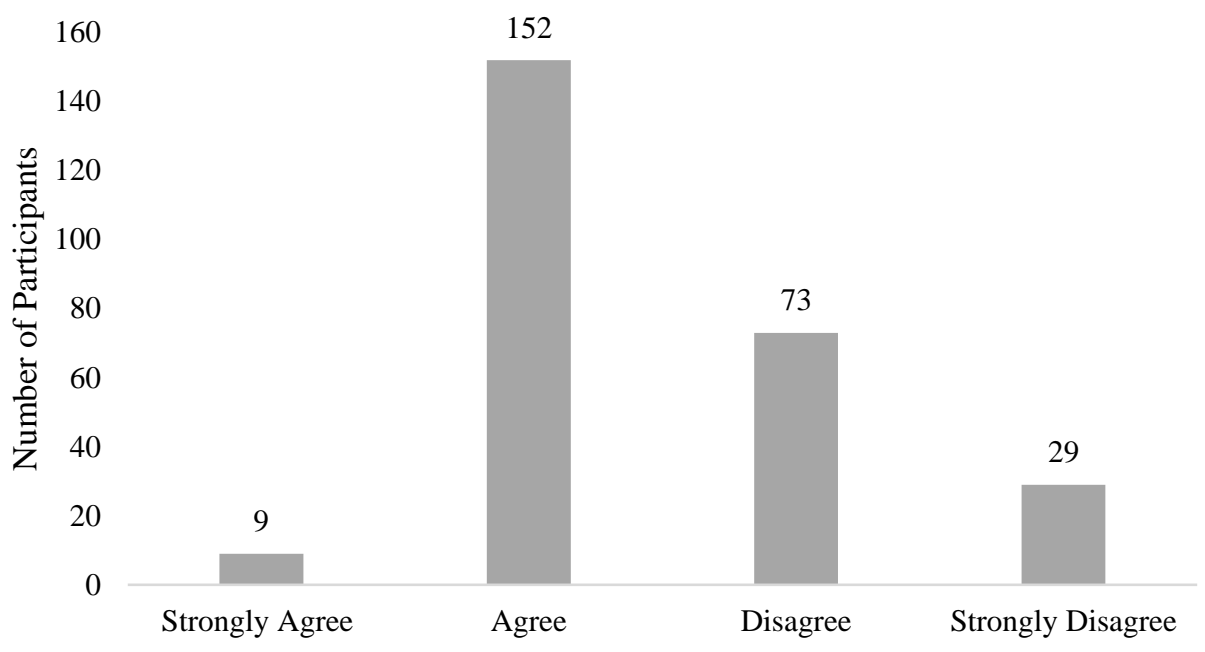

Statement 23. I do not favour physical education lessons to other lessons.

Figure 2. Survey results of statement 23

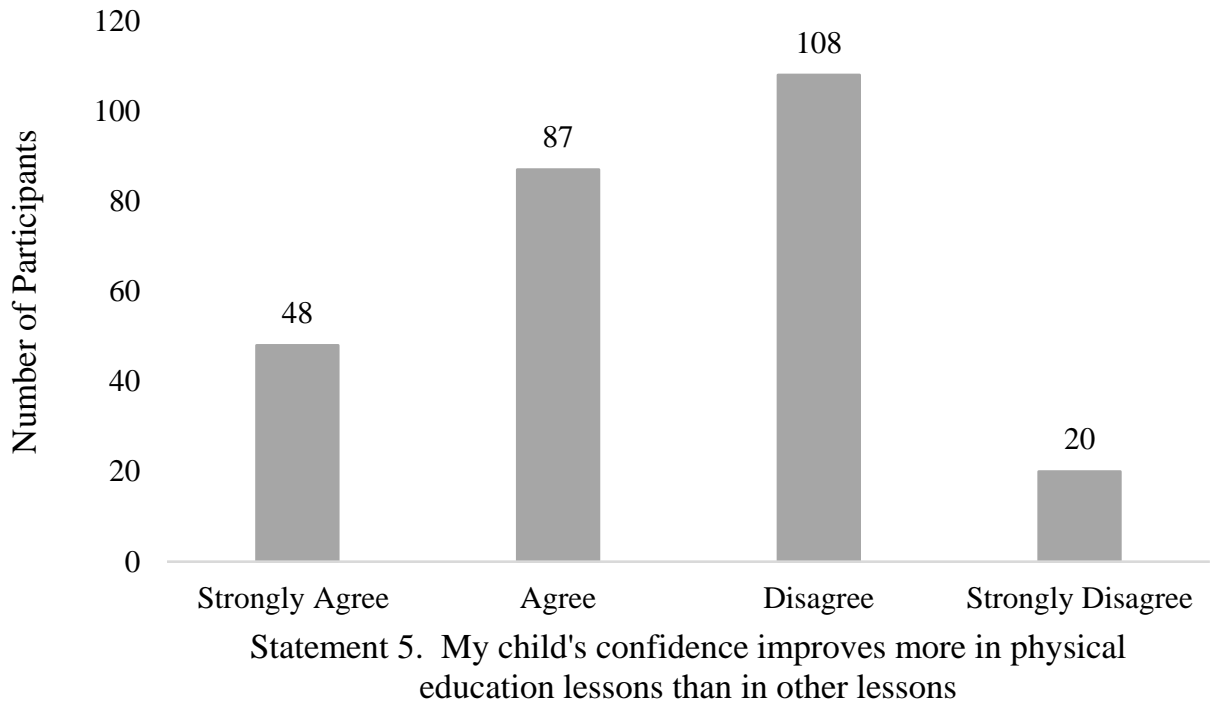

Figure 3. Survey results of statement 5 


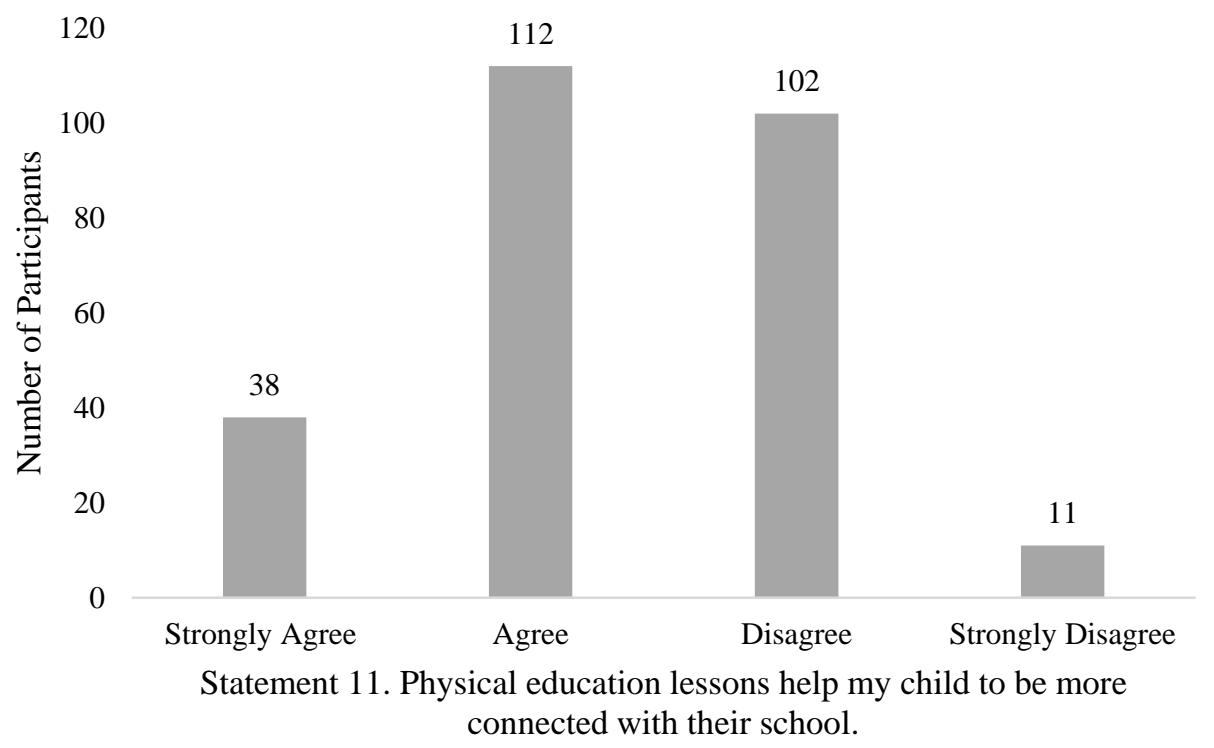

Figure 4. Survey results of statement 11

Some areas of the survey were divided in opinion. The results from the functional statements were inconclusive (Table 1) as there was not a concluding perception (Figure 3 and 4). It was important to address these differences in perception, an in-depth understanding of why parents have a split perception on the functional aspect of PE was explored through interview.

4 themes were identified from the online survey and interviews, which were: Importance of PE; Teacher-Pupil relationship; $\mathrm{PE}$ in relation to other subjects; and the competitive nature of PE. Each theme will be discussed in turn, with illustrative quotes to support the narrative. Interestingly, it is important to note that parents' own experiences did not seem to affect the perceptions they currently have on PE. Some parents explained they 'understand PE has come a long way since they were at school'.

\section{Importance of PE}

From both qualitative and quantitative findings, it is apparent that parents understand the importance of PE as a subject in secondary schools. Furthermore, with the increasing concerns of the younger generation's health (Harris, 2018), it is evident that some parents acknowledge the physical benefits PE provides. All parents mentioned the PA opportunities PE provides to pupils.

Yeah, of course, It is important to encourage children to not be couch potatoes and to get up and move their bodies a bit. We all know that. (Parent, 7)

Some parents considered the mental health benefits PE can have on their child.

I think it's vital that we encourage them to.. to be active, even if it's not a sport, but to be active. Otherwise, I think you know we're gonna have a nation that really struggles with confidence, self-esteem, health, you know, mental health (Parent, 6)

Although emphasis has been placed on parents having an understanding of the social and psychological benefits of PE, it has been identified by numerous academics for teachers to explicitly plan and teach lessons which place importance on a positive experience of PA (Harris, 2018). Furthermore, some parents were able to highlight social skills which they perceived PE to develop, alongside leadership skills, teamwork, and communication:

I think it's probably the only subject that teaches them teamwork, with resilience, with erm you know...determination, courage, there's just so many different aspects to PE and it's not just about the physical side, teaching them the social side, erm, how to interact with each other (Parent, 6)

All parents were informed that ' 2 in 5 secondary schools are cutting PE time' (YST, 2018) and asked their thoughts. Many did not realise PE was being cut by some schools in the UK and most were not happy:

That's not right. ... They shouldn't because it does help the kids. It makes their mind active. It makes their body active, the mind active and I'm sure that they'll get on with their lessons better than were they're not active. 
(Parent, 4)

However, some parents did understand why a school might cut PE as there is so much pressure on the schools to ensure they achieve results for league tables, the influence of performativity and accountability are frequently cited as pressures on schools and can explain their focus when choosing curriculum (Perryman, \& Calvert 2019).

\section{Teacher-Pupil relationship}

The findings indicated parents recognised the social skills children develop through PE lessons. However, this was only acknowledged by some of the parents in the interviews. Most parents placed great emphasis on PE teachers. Some parents appreciated the PE teachers influence on their child taking up physical activity and the parents then supported this through external activities.

My oldest son, he's in year seven, has recently taken on doing street dance out of school, which was a result of loving it in school. And it's being good at it and encouraged by his teacher and said, you know, you should take this up. (Parent, 7)

In this case, the child has blossomed in the activity because of the encouragement from the teacher. Had the teacher not encouraged the child to continue participating in the activity they may have not been as physically active. Therefore, it is vital to recognise the rapport a teacher has with a pupil and how this can affect the parent's perceptions of PE.

She's very fond of him. She always says... oh what's his name again... Mr... Mr... Mr... *****. She always says $\mathrm{Mr} * * * * *$ is always so funny. They really really get them... get the kids going. Thanks to them that I'm honest I'm so happy about it, gives them confidence and makes them a better person. (Parent, 4)

However, it should be noted that not all parents have such a positive view, one parent explained their child had little relationship with their PE teacher as their child was not a 'sporty child'. Furthermore, some parents explained the PE teacher was more valuable to their child's PA level than themselves.

'I wouldn't say a parent has an awful lot of influence personally' (Parent, 8)

\section{$P E$ in relation to other subjects}

It was important to evaluate parents perception of PE in comparison to other subjects. As shown from the results of the survey, the interview findings found there to be a divided opinion on where PE should sit in the curriculum hierarchy. Half of the parents suggested for PE to sit alongside English and Maths, and intriguingly above science. However, the other half of parents, felt more significance towards English, Maths, Science and other subjects. Although this was down to the child in question. Therefore, it is also noteworthy to acknowledge that children enjoy different subjects. A theme throughout all interviews, parents acknowledged not all children will like PE but it is important for them to find a physically engaging activity to be a part of.

\section{Competitive nature of $P E$}

Although this was not a topic in the online survey this theme came to light throughout the interviews. Parents had mixed views on the competitive nature of PE. Firstly, most parents acknowledged Secondary school PE to be more competitive than Primary school PE as they explained it was more team sports which were delivered in secondary PE lessons. It was found that parents thought PE does not suit the needs of all pupils when competing is involved. This competitive nature meant some parents had given up on encouraging their child to participate in afterschool extracurricular activities. Although this is not PE, parents tended to associate PE with extracurricular activities.

I think if my children who are relatively fit get put off sport because it's competitive at school then goodness knows what happens to the people who aren't very fit, it's a doss which I know sometimes... (Parent, 3)

On the other hand, parents reported not being entirely happy with PE as they felt their child was 'frustrated' with their PE lessons challenge:

She comes home quite frustrated with her PE lessons, and I think it's because she's been coached she plays a sport herself and when she goes to her PE lessons she doesn't really feel she's getting a great deal out of the lesson itself. (Parent, 6)

When further exploring why parents in the survey felt PE did not connect their child to their school, similar results emerged in the interviews. Some parents felt a lack of connection because their child was not able to participate in the clubs due to the competitive nature of the clubs:

\section{Discussion}

Four themes in relation to parental perception on secondary school PE were identified and demonstrated understanding of the importance of PE in the education system, however, there is recognition of flaws in the subject. The perceptions 
and perspectives of parents can help schools to understand how they may be able to better support pupils and families in PE. The quantitative data collected provides an insight into what parents' perceptions are. Similar to previous investigations conducted in other countries worldwide (Na, 2015; Yilmaz, 2018), parents in this study have mainly positive perceptions of the importance of $\mathrm{PE}$ and consequently, understand the necessity for the subject in the curriculum. YouGov found $42 \%$ of British adults ranked PE as very important and more important than other subjects on the curriculum such as citizenship, design and technology, geography, history and religious studies (The Telegraph, 2018). Similar was found in this study with half of the survey respondent parents identifying in PE in the top three subjects when ranking subject importance, alongside English and Maths.

The findings from both the survey and the interviews have shown parents acknowledgement to the benefits PE has on physical and mental wellbeing. With the rise of obesity, it is increasingly essential for parents to be aware of the importance of PA as a preventive strategy. These findings demonstrate the growing awareness parents have of the crucial role PE plays in health and wellbeing for pupils. The results from this study where parents understood the positives of being physically active through PE supports the Thompson et al. (2010) study, where the majority of parents regarded family engagement in PA as significant, what is more recognised advantages including improved mental health, physical fitness and weight control. Furthermore, parents from the study recognised that's PE is a unique subject that teaches them teamwork, resilience, determination, courage, and other wide skills (Corredor, 2015). With Cale and Harris (2018) stated high-quality PE can support the development of pupils self-esteem and self-worth; confidence; reduce symptoms of anxiety and depression; heighten social development by aiding pupils to cooperate, compete and to develop a sense of respect fairness, and justice; benefit cognitive function and academic achievement; and encourage school attendance. It is important for parents to be aware of this and support this matter.

A study conducted by Youth Employment UK (2017) reported teamwork, communication, self-management, problemsolving and self-belief as the core skills most valued by employers. In support of this, Harris (2018) states high-quality PE enhances pupils employability by significantly contributing to their development of these skills. However, the social skills developed in PE was not acknowledged by all parents. Therefore, some parents may not understand the social skills which can be developed through quality PE lessons or they feel their child does not get these type of PE lessons. Future researchers may consider investigating this further, to develop greater understanding. Furthermore, Coulter et al. (2019) reported parents valued 'sportsmanship', therefore it is evident that parents in that study acknowledge the social skills developed when a child attends PE lessons.

The PE environment is unique compared to other subjects in the curriculum, the physical, mental and social benefits are reasons why it has such a unique nature (Koekoek \& Knoppers 2015; Ciotto \& Gagnon 2018). Several of the parents in the present study also labelled PE as a unique subject because of all the previously mentioned ways it developed pupils. It remains a concern, despite the recognised benefits, that within schools there are increasing pressures to improve academic scores will often lead to additional time for subjects such as Maths and English at the cost of time for pupils to be physically active (Singh et al., 2012). When the YST (2018) statistic of 2 in 5 secondary schools cutting PE time was shared with parents, two thirds of parents were not aware that this was happening and all eights parents were not happy with this, maybe this is though is to be an expected outcome as this is seldom discussed with parents (Mkandawire, et al 2018). However, two parents expressed they would want this to happen if they're child was struggling in 'more important subjects'. Coulter et al. (2019) recent study found $61 \%$ of parents felt that schools allocation time for PE should be increased and suggested they would like to see PE increasing from 2 hours a week to scheduling daily PE. These findings are similar to the current findings in this study.

The results suggest parents identify the role of the PE teacher as being very important in supporting a child's PA engagement, however Olivares et al. (2015) findings indicated parents' influence is more significant than the influence a PE teachers' regardless of age, sex and physical condition. Therefore, it is fundamental parents play a part in their child's physical activity engagement. This is also apparent in the research conducted by Jin et al. (2011), who found when pupils are making their Key Stage 4 options they took advice mostly from their parents. Parents do not have access to PE lessons and have limited access to the participation their child does in extracurricular activities for various different reasons. However, due to the lack of access to observe first-hand PE apart from extracurricular activities, this can hinder support and feedback (Na, 2015).

The parents in this study expressed both positive and concerning thoughts on the supposed competitive nature PE lessons have. Although there are claimed benefits to having competition in PE lessons, which were acknowledged by some parents, such as developmental effects for a healthy lifestyle, where pupils learn about physical, social and cognitive skills (Choi et al., 2014; Ramey and Rose-Krasnor, 2012). Similar concerns have been echoed in a study conducted in Ireland by Coulter et al. $(2019,9)$, where $95.7 \%$ of parents reported competition to be the least important outcome for their child when participating in PE based on the options available to them, ' $41.4 \%$ of parents reported that their child felt 'bad if I lose at PE or games'. It has also been stated by Wintle (2018) pupils could be at risk of possible negative impact on their 
self-esteem and comparing oneself to others is not always healthy (Merkel, 2013). In addition, it has been reported by Ennis (1996) that many pupils may experience alienation while participating in competitive sport in PE lessons. Stolz (2014) also deemed it to be a harrowing experience for some pupils and therefore, parents who showed concerns about the level of competitiveness in PE have evidently understandable concerns which should be addressed.

Furthermore, the concerns regarding PE lessons are similar to the concerns parents had with extracurricular activities. Although, extracurricular is not a part of the curriculum, from the findings it should be acknowledged the vast amount of opinion parents had on this matter. It was evident that some parents felt extra-curricular activities delivered by the PE department were only for the 'sporty' and 'competitive pupils' in a school. Consequently, a couple of parents perceived their child had no place going to the activities, as they believed their child was fit and healthy but not competitive. There are many benefits to pupils participating in extracurricular activities (Martinez et al., 2016), as it can increase a child's PA levels. As mentioned above, there are numerous positive outcomes from being physically active such as physical and mental health, social wellbeing, academic and cognitive performance (Bailey et al., 2013; Public Health England, 2014). Furthermore, Lleras (2008) found that participation in sports activities was associated with higher educational attainment and job earnings. Despite this, in a recent case study Stirrup (2018) highlighted that coaches, who were involved in delivering extracurricular clubs, fostered a competitive environment to ensure the school was able to perform to a high standard at school fixtures and competitions. This meant pupils were purposefully selected for the clubs and pupils who wanted to attend but did not perform to the desired standard were rejected.

Sprake and Temple (2016) stated the approach PE has with competition reflects the Government's view of PE as a way of continuing to legitimise traditional games and specific forms of sport. However, currently, the government are encouraging the support PA has on mental and physical health. Research from the YST (2018) has stated teachers should be careful using approaches that match pupils' motivations which will aim to avoid alienating those who lack in ability or interest of the competitive standard (Sprake and Temple, 2016). Therefore, from the findings, it is apparent that this has not met parents' perceptions and the competitive element of PE is an issue which should be addressed. In addition, Choi et al. (2014) also recognised how pupils experience, in terms of child development, competition was very dependable on how the competitions were designed and how the experiences were perceived. Therefore, it is vital schools and PE teachers get the right balance of competition in PE lessons and extracurricular activities. Therefore, it is evident from a range of studies that not all parents agree that PE suits their child, whether this is because the lesson is too competitive or is not challenging enough. However, it should be considered that most secondary schools have a large number of pupils in PE lessons making it hard to cater to every pupil's needs in one lesson.

\section{Conclusion and Recommendations}

The status of PE declining when compared with other subjects in the curriculum, there are numerous academics who have recognised the need to improve the status (Capel \& Whitehead, 2015; Green, 2008; Green and Hardman, 2011; Harris, 2018; Kirk et al., 2013; Randall et al., 2016). Furthermore, parents are a significant part of a child's life and can an impact on the experiences a child goes through (Erdener and Knoeppel, 2018).

It is evident the majority of parents understand the importance of the subject but have differing views. Some parents have concerns regarding their child's PE being too competitive, which has led to some pupils feeling a lack of confidence and feeling like they are unable to participate in extracurricular activities, there is recognition from parents that the subject has developed from parents interviewed. Furthermore, when relating PE to other subjects there was also a divide on perceptions, with some parents stating they understand why PE would be cut. Importantly $50 \%$ percent of parents did believe that PE is as important as subjects such Maths, English and Science, but, in comparison to other subjects $61 \%$ of parents do not favour PE overall. The findings demonstrate that parents have an awareness of the role PE plays in improving health and wellbeing for pupils. Parents recognise the role of the PE teacher as being significant in supporting a children's PA levels, but previous research indicates parents' influence is more important (Olivares et al, 2015).

Further research is required however this study could be a catalyst for greater exploration. It is evident there is an importance to educate parents on the role they have in terms of their child's PA and PE engagement and participation. Future research should continue to explore parents' perceptions of PE in the UK and how parents can be supported and educated.

\section{Limitations}

It is important to recognise that challenges to mixed methods research researcher due to difficulties in blending both data sets and with the survey only having close-ended questions, therefore participants were not able to develop their responses and the first stage of data collection did now allow depth or much flexibility ((Johnson and Onwuegbuzie, 2004; Cohen et al, 2018). Also a relatively small sample of qualitative data was collected. 


\section{Acknowledgements}

Ethical approval was given before collection of all data.

\section{Data Availability Statement}

Data available on request from the authors.

\section{References}

Alguacil, M. (2018). Analysis of the opinion on physical education in high schools and the extracurricular sports practice of students and their personal environment. Journal of Physical Education and Sport, 18(3), 1646-1653. https://doi.org/10.7752/jpes.2018.03241

Anderson, K. J., \& Minke, K. M. (2007). Parent Involvement in Education: Toward an Understanding of Parents' Decision Making. The Journal of Educational Research 100(5), 311-23. https://doi.org/10.3200/JOER.100.5.311-323

Bailey, R. (2006). Physical Education and Sport in Schools: A Review of Benefits and Outcomes. Journal of School Health 76(8), 397-401. https://doi.org/10.1111/j.1746-1561.2006.00132.x

Bailey, R. (2010). The Sage Handbook of Philosophy of Education. Los Angeles: Sage.

Bailey, R. Armour, K., Kirk, D., Jess, M., Pickup, I., Sandford, R., \& BERA Physical Education and Sport Pedagogy Special Interest Group (2009). The Educational Benefits Claimed for Physical Education and School Sport: An Academic Review. Research Papers in Education, 24(1), 1-27. https://doi.org/10.1080/02671520701809817

Bailey, R., Hillman, C., Arent, S., \& Petitpas, A. (2013). Physical Activity: An Underestimated Investment in Human Capital? Journal of physical activity \& health, 10(3), 289-308. https://doi.org/10.1123/jpah.10.3.289

Bartram, B. (2006). An Examination of Perceptions of Parental Influence on Attitudes to Language Learning. Educational Research, 48(2), 211-21. https://doi.org/10.1080/00131880600732298

Bebetsos, E., \& Antoniou, P. (2008). University Students' Differences on Attitudes towards Computer Use. Comparison with Students' Attitudes towards Physical. Activity Digital Education Review 17, 20-28.

Beets, M., Cardinal, J., \& Alderman, B. (2010). Parental Social Support and the Physical Activity-Related Behaviors of Youth: A Review. Health Education \& Behavior, 37(5), 621-644. https://doi.org/10.1177/1090198110363884

Blair, R., \& Capel, S. (2011). Primary Physical Education, Coaches and Continuing Professional Development. Sport, Education and Society, 16(4), 485-505. https://doi.org/10.1080/13573322.2011.589645

Brown, R., Brown, J., Reardon, K., \& Merrill, C. (2011). Understanding STEM: Current perceptions. Technology and Engineering Teacher, 70(6), 5-9.

Brustad, R. J. (1996). Attraction to Physical Activity in Urban Schoolchildren: Parental Socialization and Gender Influences. Research Quarterly for Exercise and Sport, 67(3), 316-323. https://doi.org/10.1080/02701367.1996.10607959

Bryman, A. (2008). Social Research Methods. UK: Oxford University Press

Cale, L., \& Harris, J. (2018). The Role of Knowledge and Understanding in Fostering Physical Literacy. Journal of Teaching in Physical Education 37(3), 280-87. https://doi.org/10.1123/jtpe.2018-0134

Campbell, M. K., Allicock H. M., Resnicow, K., Blakeney, N., Paxton, A., \& Baskin, M. (2007). Church-Based Health Promotion Interventions: Evidence and Lessons Learned. Annual review of public health, 28(1), $213-234$. https://doi.org/10.1146/annurev.publhealth.28.021406.144016

Capel, S., \& Whitehead, M. (2015). Learning to Teach Physical Education in the Secondary School. London: Routledge. https://doi.org/10.4324/9781315767482

Carlson, T. B. (1995). We Hate Gym: Student Alienation from Physical Education. Journal of Teaching in Physical Education, 14(4), 467-477. https://doi.org/10.1123/jtpe.14.4.467

Choi,H, S. Johnson, B. \& Kim, Y,K. (2014). Children's Development Through Sports Competition: Derivative, Adjustive, Generative, and Maladaptive Approaches. Quest, 66(2), 191-202. https://doi.org/10.1080/00336297.2013.861757

Chomitz, V. R., Slining, M. M., McGowan, R. J., Mitchell, S. E., Dawson, G. F., \& Hacker, K. A. (2009). Is There a Relationship Between Physical Fitness and Academic Achievement? Positive Results From Public School Children in the Northeastern United States. The Journal of school health, 79(1), 30-37. https://doi.org/10.1111/j.17461561.2008.00371.x

Ciotto, C. M. \&, Gagnon, A. G. (2018). Promoting Social and Emotional Learning in Physical Education. Journal of 
Physical Education, Recreation \& Dance, 89(4), 27-33. https://doi.org/10.1080/07303084.2018.1430625

Clement, D., Brooks, D., \& Wilmoth, B. (2009). Parental attitudes towards Physical activity: A preliminary analysis. I.J. Fitness, 5(2), 1-11.

Cohen, L. Manion, L., \& Morrison, K. (2018). Research Methods in Education. London: Routledge. https://doi.org/10.4324/9781315456539

Corredor, C. (2015). The Effects of Physical Education on Academic Achievement, Children and Youth Studies, Brooklyn College. Available at: https://arcs15.commons.gc.cuny.edu/the-effects-of-physical-education-on-academicachievement/ (accessed 6th September 2017).

Coulter, M., McGrane, B., \& Woods, C. (2019). 'PE Should Be an Integral Part of Each School Day': Parents' and Their Children's Attitudes towards Primary Physical Education. Education 3-13, 1-17. https://doi.org/10.1080/03004279.2019.1614644

Creswell, J. W., \& Plano Clark, V. L. (2018). Designing and Conducting Mixed Methods Research. Los Angeles: Sage.

Currie, C., Levin, K., Kirby, J., Currie, D., Van Der Sluij, W., \& Inchley, J. (2011). Health Behaviour in School-aged Children. National Report. 2010 HBSE survey in Scotland.

Davis-Kean, P. E. (2005). The Influence of Parent Education and Family Income on Child Achievement. Journal of Family Psychology, 19(2), 294-304. https://doi.org/10.1037/0893-3200.19.2.294

Davison, K. K. (2004). Activity-Related Support from Parents, Peers, and Siblings and Adolescents' Physical Activity: Are There Gender Differences? Journal of Physical Activity and Health, 1(4), $363-76$. https://doi.org/10.1123/jpah.1.4.363

Department of Education (1989). The National Curriculum. London: HMSO.

Department of Education (2013). The National Curriculum in England: Key stages 1 and 2 framework document. London: Crown Copyright.

Department of Education (2014). Assessment Principles. London: Crown Copyright

Desimone, L. (1999). Linking Parent Involvement With Student Achievement: Do Race and Income Matter? The Journal of Educational Research 93(1), 11-30. https://doi.org/10.1080/00220679909597625

Dwyer, G. M., Higgs, J., Hardy, L. L., \& Baur, L. A. (2008). What Do Parents and Preschool Staff Tell Us about Young Children's Physical Activity: A Qualitative Study. The International Journal of Behavioral Nutrition and Physical Activity, 5(1), 66. https://doi.org/10.1186/1479-5868-5-66

Ennis, C. D. (1996). Students' Experiences in Sport-Based Physical Education: More Than Apologies Are Necessary. Quest, 48(4), 453-56. https://doi.org/10.1080/00336297.1996.10484211

Erdener, M. A., \& Knoeppel, R. C. (2018). Parents' Perceptions of Their Involvement in Schooling. International Journal of Research in Education and Science, January1-13. https://doi.org/10.21890/ijres.369197

Erola, J., Jalonen, S., \& Lehti, H. (2016). Parental Education, Class and Income over Early Life Course and Children's Achievement. Research in Social Stratification and Mobility, 44(44), 33-43. https://doi.org/10.1016/j.rssm.2016.01.003

Erwin, H., Fedewa, A., Beighle, A., \& Ahn, S. (2012). A Quantitative Review of Physical Activity, Health, and Learning Outcomes Associated With Classroom-Based Physical Activity Interventions. Journal of Applied School Psychology 28(1), 14-36. https://doi.org/10.1080/15377903.2012.643755

Evans, J. (1986). Physical Education, Sport and Schooling. London: Falmer Pr.

Fan, W., \& Williams, C. M. (2010). The Effects of Parental Involvement on Students' Academic Self-Efficacy, Engagement and Intrinsic Motivation. Educational Psychology 30(1), 53-74. https://doi.org/10.1080/01443410903353302

Feinstein, L., \& Sabates, R. (2006). Does Education Have an Impact on Mothers' Educational Attitudes and Behaviours? [Wider Benefits of Learning Research Report No. 16]. Centre for Research on the Wider Benefits of Learning, Institute of Education, University of London.

Fleet, M. (2020). Through the eyes of those that teach physical education policy change and political reforms, in Springer Encloypedia of Teacher Education, Springer, Singapore.

Flick, U. (2014). An Introduction to Qualitative Research. Los Angeles: Sage.

Graue, M. E., \& Walsh, D. J. (1998). Studying Children in Context. US: Sage. 
Green, C. L., Walker, J. M. T., Hoover-Dempsey, K. V., \& Sandler, H. M. (2007). Parents' Motivations for Involvement in Children's Education. Journal of Educational Psychology 99(3), 532-44. https://doi.org/10.1037/00220663.99.3.532

Green, K. (2008). Understanding Physical Education. London: Sage.

Green, K., \& Hardman, K. (2005). Physical Education: Essential Issues. London: Sage.

Griggs, G. (2007). Physical Education: Primary Matters, Secondary Importance. Education 3-13: International Journal of Primary, Elementary and Early Years Education, 35(1), 59-69. https://doi.org/10.1080/03004270601103350

Griggs, G. (2010). For Sale - Primary Physical Education. £20 per Hour or Nearest Offer. Education 3-13: International Journal of Primary, Elementary and Early Years Education, 38(1), 39-46. https://doi.org/10.1080/03004270903099793

Haapala, E. A. (2013). Cardiorespiratory Fitness and Motor Skills in Relation to Cognition and Academic Performance in Children - A Review. Journal of Human Kinetics, 36(1), 55-68. https://doi.org/10.2478/hukin-2013-0006

Harris, J. (2018). The Case for Physical Education Becoming a Core Subject in the National Curriculum. Physical Education Matters, 13(2), 9-12.

Hassmén, P., Koivula, N., \& Uutela, A. (2000). Physical Exercise and Psychological Well-Being: A Population Study in Finland. Preventive Medicine, 30(1), 17-25. https://doi.org/10.1006/pmed.1999.0597

Hastie, P. (2016) The Philosophy of Physical Education: A New Perspective. Journal of the Philosophy of Sport, 43, 327329. https://doi.org/10.1080/00948705.2016.1165620

Health Survey for England (2018). Health Survey for England 2018 Physical Activity in Children.

Hodge, S. R., \& Jansma, P. (1999). Effects of Contact Time and Location of Practicum Experiences on Attitudes of Physical Education Majors. Adapted Physical Activity Quarterly, 16(1), 48-63. https://doi.org/10.1123/apaq.16.1.48

Horton, H. (2018). PE is a more important school subject than history, survey by YouGov finds. The Telegraph. 15 February, 18.

Houston, J., \& Kulinna, P. (2014). Health-Related Fitness Models in Physical Education. Strategies, 27(2), 20-26. https://doi.org/10.1080/08924562.2014.879026

Hüseyin, U., Karahan, M., Öner, M., \& Aydos, L. (2011). Komparativna Analiza: Stavovi Turskih Učenika i Stranih Učenika Prema Nastavi Tjelesnog Odgoja. Croatian Journal of Education 13.

Inchley, J., Kirby, J., \& Currie, C. (2011). Longitudinal Changes in Physical Self-Perceptions and Associations with Physical Activity during Adolescence. Pediatric Exercise Science, 23(2), 237-49. https://doi.org/10.1123/pes.23.2.237

Jin, W., Muriel, A., \& Sibieta, L. (2011). Subject and Course Choices at Ages 14 and 16 amongst Young People in England. London: Department for Education.

Johnson, R. B., \& Onwuegbuzie, A. J. (2004). Mixed Methods Research: A Research Paradigm Whose Time Has Come. Educational Researcher, 33(7), 14-26. https://doi.org/10.3102/0013189X033007014

Jones, I., Brown, L., \& Holloway, I. (2013). Qualitative Research in Sport and Physical Activity. London: Sage. https://doi.org/10.4135/9781473914995

Kirk, D., Macdonald, D., \& O'Sullivan, M. (2013). The Handbook of Physical Education. London: Sage

Koca, C., Aşçi, F. H., \& Demirhan, G. (2005). Attitudes toward Physical Education and Class Preferences of Turkish Adolescents in Terms of School Gender Composition. Adolescence, 40(158), 365-75.

Koekoek, J., \& Knoppers, A. (2015). The Role of Perceptions of Friendships and Peers in Learning Skills in Physical Education. Physical Education and Sport Pedagogy, 20(3), 231-249. https://doi.org/10.1080/17408989.2013.837432

Li, Y., Zhai, F., Yang, X., Schouten. E, G., Hu, X., He, Y., Luan, D., \& Ma, G. (2007). Determinants of Childhood Overweight and Obesity in China. British Journal of Nutrition, 97(1), 210-15. https://doi.org/10.1017/S0007114507280559

Lleras, C. (2008). Do Skills and Behaviors in High School Matter? Social Science Research 37(3), 888-902. https://doi.org/10.1016/j.ssresearch.2008.03.004 
Martinez, A., Coker, C., McMahon, S. D. Cohen, J., \& Thapa, A. (2016). Involvement in Extracurricular Activities: Identifying Differences in Perceptions of School Climate. The Educational and Developmental Psychologist, 33(1), 70-84. https://doi.org/10.1017/edp.2016.7

McKenzie, T. L., \& Lounsbery, M. A. F. (2014). The Pill Not Taken. Research Quarterly for Exercise and Sport, 85(3), 287-92. https://doi.org/10.1080/02701367.2014.931203

McNamee, M. (2005). The Nature and Values of Physical Education. London: Sage

Merkel, D. (2013). Youth Sport: Positive and Negative Impact on Young Athletes. Open Access Journal of Sports Medicine 2013, 151-60. https://doi.org/10.2147/OAJSM.S33556

Miller, K. E. Melnick, M. J. Barnes, G. M. Farrell, M. P., \& Sabo, D. (2005). Untangling the Links among Athletic Involvement, Gender, Race, and Adolescent Academic Outcomes. Sociology of Sport Journal, 22(2), 178-193. https://doi.org/10.1123/ssj.22.2.178

Mkandawire, M. T. Maulidi, F. K. Sitima, J., \& Luo, Z. (2018). Who Should Be Deciding What to Be Taught in Schools? Perspectives From Secondary School Teacher Education in Malawi. Journal of Medical Education and Curricular Development. https://doi.org/10.1177/2382120518767903

Morgan, P. J., Saunders, K. L., \& Lubans, D. R. (2012). Improving Physical Self-Perception in Adolescent Boys from Disadvantaged Schools: Psychological Outcomes from the Physical Activity Leaders Randomized Controlled Trial. Pediatric Obesity, 7(3), 27-32. https://doi.org/10.1111/j.2047-6310.2012.00050.x

Mulvihill, C., Rivers, K., \& Aggleton, P. (2000). A Qualitative Study Investigating the Views of Primary-Age Children and Parents on Physical Activity. Health Education Journal, 59(2), 166-79. https://doi.org/10.1177/001789690005900206

Na, J. (2015). Parents' Perceptions of Their Children's Experiences in Physical Education and Youth Sport. The Physical Educator 72(1), 139-167.

NHS (2018). Physical activity guidelines for children and young people. Available at: www.nhs.uk/livewell/exercise/physical-activity-guidelines-children-and-young-people

Öncü, E., \& Güven, Ö. (2011). Beden eğitimi dersine yönelik ana-baba tutum ölçeğinin geliştirilmesi. Niğde Üniversitesi Beden Eğitimi ve Spor Bilimleri Dergisi, 5(3), 184-195.

Onwuegbuzie, A. J., \& Teddlie, C. (2003). A Framework for Analyzing Data in Mixed Methods Research. In Handbook of Mixed Methods in Social and Behavioral Research. A. Tashakkori and C. Teddlie, eds. Pp. 351-383. Thousand Oaks, CA: Sage.

Ornelas, I. J., Perreira, K. M., \& Ayala, G. X. (2007). Parental Influences on Adolescent Physical Activity: A Longitudinal Study. The International Journal of Behavioral Nutrition and Physical Activity, 4(1). https://doi.org/10.1186/14795868-4-3

Oxley, J. (1998). Never mind literacy and numeracy what about physical education? Bulletin of Physical Education, 21(1), 55-57.

Patton, M. Q. (2015). Qualitative Research \& Evaluation Methods. Los Angeles: Sage

Perlman, D. (2014). Motivating the Student: Sport Education Can Be a Framework for Success. Journal of Physical Education, Recreation and Dance, 85(6), 12-16. https://doi.org/10.1080/07303084.2014.926845

Perryman, J., \& Calvert, G. (2019). What motivates people to teach, and why do they leave? Accountability, performativity and teacher retention. British Journal of Educational Studies. https://doi.org/10.1080/00071005.2019.1589417

Public Health England (2014). The link between pupil health and wellbeing and attainment.

Ramey, H. L., \& Rose-Krasnor, L. (2012). Contexts of Structured Youth Activities and Positive Youth Development. Child Development Perspectives, 6(1), 85-91. https://doi.org/10.1111/j.1750-8606.2011.00219.x

Randall, V., \& Fleet, M. (2020). Constructing Knowledge in Primary Physical Education: A Critical perspective from preservice teachers. Curriculum Studies in Health and Physical Education, 2(1), 20-35. https://doi.org/10.1080/25742981.2020.1866439

Randall, V., Richardson, A., Swaithes, W., \& Adam, S. (2016). Generation Next: The preparation of pre-service teachers in primary physical education. Report, University of Winchester, UK. 
Raudsepp, L. (2006). The Relationship between Socio-Economic Status, Parental Support and Adolescent Physical Activity. Acta Paediatrica, 95(1), 93-98. https://doi.org/10.1080/08035250500323772

Reid, A. (1996). Knowledge, Practice and Theory in Physical Education. European Physical Education Review, 2(2), 94104. https://doi.org/10.1177/1356336X9600200202

Roulston, K. (2001). Data Analysis and 'Theorizing as Ideology'. Qualitative Research, 1(3), 279-302. https://doi.org/10.1177/146879410100100302

Sheehy, D. A. (2006). Parents' Perceptions of Their Child's 5th Grade Physical Education Program. The Physical Educator 63(1), 30-37.

Shephard, R. J. (1996). Habitual Physical Activity and Academic Performance. Nutrition Reviews, 54(4), 32-36. https://doi.org/10.1111/j.1753-4887.1996.tb03896.x

Silverman, D. (2016). Qualitative Research. London: Sage

Singh, A., Uijtdewilligen, L., Twisk, J., Van Mechelen, W., \& Chinapaw, M. (2012). Physical Activity and Performance at School: A Systematic Review of the Literature Including a Methodological Quality Assessment. Archives of Pediatrics \& Adolescent Medicine, 166(1), 49-55. https://doi.org/10.1001/archpediatrics.2011.716

Sprake, A., \& Temple, C. (2016). Physical Education or Physical Entertainment: where's the education in PE? Journal of Qualitative Research in Sports Studies, 10(1), 157-176.

Stidder, G., \& Hayes, S. (2016). The Really Useful Physical Education Book. London: Routledge. https://doi.org/10.4324/9781315643335

Stirrup, J. (2018). Performance Pedagogy at Play: Pupils Perspectives on Primary PE. Sport, Education and Society December, 1-13. https://doi.org/10.1080/13573322.2018.1554562

Stolz, S. A. (2014). Theœ Philosophy of Physical Education. London: Routledge. https://doi.org/10.4324/9781315762258

Subramaniam, P. R., \& Silverman, S. (2007). Middle School Students' Attitudes toward Physical Education. Teaching and Teacher Education, 23(5), 602-11. https://doi.org/10.1016/j.tate.2007.02.003

Teddlie, C. and Tashakkori, A. (2009). Foundations of Mixed Methods Research. Thousand Oaks: Sage.

Thompson, J. L., Jago, R., Brockman, R., Cartwright, K., Page, A. S., \& Fox, K. R. (2010). Physically Active Families De-Bunking the Myth? A Qualitative Study of Family Participation in Physical Activity. Child: Care, Health and Development, 36(2), 265-74. https://doi.org/10.1111/j.1365-2214.2009.01051.x

Trigwell, J., Murphy, R. C., Cable, N. T., Stratton, G., \& Watson, P. M. (2015). Parental Views of Children's Physical Activity: A Qualitative Study with Parents from Multi-Ethnic Backgrounds Living in England. BMC public health, 15(1), 1005. https://doi.org/10.1186/s12889-015-2351-8

Trost, S. G., Pate, R. R., Saunders, R., Ward, D. S., Dowda, M., \& Felton, G. (1997). A Prospective Study of the Determinants of Physical Activity in Rural Fifth-Grade Children. Preventive Medicine, 26(2), 257-63. https://doi.org/10.1006/pmed.1996.0137

Van Holland De Graaf, J., Hoogenboom, M., De Roos, S., \&Freek, B. (2018). Socio-Demographic Correlates of Fathers' and Mothers' Parenting Behaviors. Journal of Child and Family Studies, 27(7), 2315-27. https://doi.org/10.1007/s10826-018-1059-7

Welk, G. J., \& Eklund, B. (2005). Validation of the Children and Youth Physical Self Perceptions Profile for Young Children. Psychology of Sport \& Exercise, 6(1), 51-65. https://doi.org/10.1016/j.psychsport.2003.10.006

White, J. (2006). Intelligence, Destiny and Education. London: Routledge Ltd. https://doi.org/10.4324/9780203029190

Wintle, J. (2018). Managing Competition in Physical Education: Promoting the Positive. Physical Education Matters.

Wittberg, R., Cottrell, L. A., Davis, C. L., \& Northrup, K. L. (2010). Aerobic Fitness Thresholds Associated with Fifth Grade Academic Achievement. American Journal of Health Education, 41(5), 284-91. https://doi.org/10.1080/19325037.2010.10599155

Woods, A. M., Graber, K. C., \& Newman, D. (2012). Children's Recess Physical Activity: Movement Patterns and Preferences. Journal of Teaching in Physical Education, 31(2) 146-162. https://doi.org/10.1123/jtpe.31.2.146

Wright, M. S., Wilson, D. K., Griffin, S., \& Evans, A. (2010). A Qualitative Study of Parental Modeling and Social Support for Physical Activity in Underserved Adolescents. Health Education Research, 25(2), 224-32. https://doi.org/10.1093/her/cyn043 
Yilmaz, A. (2018). Attitudes towards physical education course and extracurricular sport activities of parents. Niğde Üniversitesi Beden Eğitimi Ve Spor Bilimleri Dergisi, 12(1), 48-64.

Yin, R. K. (2009). Case Study Research. Applied Social Research Methods Series 5. Los Angeles: Sage.

Youth Employment UK (2017). Employability Review.

Youth Sport Trust (2018). PE provision in secondary schools. Youth Sport Trust Research and Insight Team.

\section{Copyrights}

Copyright for this article is retained by the author(s), with first publication rights granted to the journal.

This is an open-access article distributed under the terms and conditions of the Creative Commons Attribution license which permits unrestricted use, distribution, and reproduction in any medium, provided the original work is properly cited. 